\title{
KARAKTERISTIK DAN ORGAN REPRODUKSI BETINA KANGURU POHON KELABU (Dendrolagus inustus) DI PAPUA
}

\section{THE CHARACTERISTICS AND FEMALE REPRODUCTIVE ORGAN OF GRAY TREE KANGAROO (Dendrolagus inustus) IN PAPUA}

\author{
Johan Fredrik Koibur $^{1 *}$, Kustono ${ }^{2}$, dan Diah Tri Widayati ${ }^{2}$ \\ ${ }^{1}$ Fakultas Peternakan Perikanan dan Ilmu Kelautan, Universitas Negeri Papua, Jl. Gunung Salju, Amban, Manokwari, \\ Papua Barat, 98314 \\ ${ }^{2}$ Fakultas Peternakan, Universitas Gadjah Mada, Jl. Fauna No. 3, Bulaksumur, Yogyakarta, 55281
}

\section{INTISARI}

Lima ekor betina Kanguru Pohon Kelabu (Dendrologus inustus) dewasa dengan rerata umur $1 \mathrm{~s} / \mathrm{d} 2,5$ tahun, bobot badan 10,83 $\mathrm{kg}$ dan panjang tubuh $72,8 \mathrm{~cm}$, dibedah memakai peralatan bedah dan diambil organ reproduksinya. Karakteristik organ reproduksi didokumentasikan dengan kamera digital, diukur dan ditimbang. Penelitian ini menggunakan metode studi eksperimen deskriptif dengan teknik studi kasus. Analisis data menggunakan statistik deskriptif dan korelasi bagi beberapa informasi yang dibutuhkan lalu ditampilkan dalam nilai rerata dan standar deviasi (SD). Hasil pengamatan diperoleh panjang organ reproduksi betina D. inustus berkisar $18,88 \pm 0,78 \mathrm{~cm}$ (kiri) dan $19,00 \pm 0,78 \mathrm{~cm}$ (kanan) dengan panjang ovarium berkisar $1 \mathrm{~cm}$ (kiri/kanan) dengan berat berkisar 0,59 $\pm 0,85 \mathrm{~g}$ (kiri) dan $1 \mathrm{~g}$ (kanan). Diameter dan panjang tuba fallopi, cornu uteri, corpus uteri, dan serviks masing-masing adalah: 0,57 $\pm 0,01$

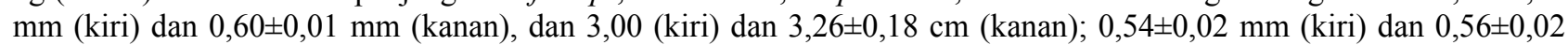

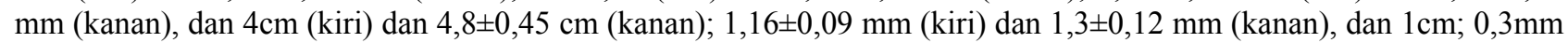
(kiri/kanan) dan $3 \mathrm{~cm}$ (kiri/kanan), sedangkan panjang vagina dan vulva berturut-turut adalah 4 dan $2 \mathrm{~cm}$. Hasil studi menunjukkan bahwa bentuk dan model organ reproduksi D. inustus menyerupai organ betina mamalia umumnya, namun semua organ berjumlah dua dengan sekat yang tampak jelas serta ukurannya yang berbeda.

(Kata kunci: Kanguru Pohon Kelabu, Organ reproduksi betina)

\section{ABSTRACT}

Five females of 1 up to 2.5 years old Gray Tree Kangaroo (Dendrologus inustus), $10.83 \mathrm{~kg}$ body weight and 72.8 $\mathrm{cm}$ body length were dissected, and then the reproductive organ were observed for its morphology, length, and weight using digital camera, tape measured and scale. This study used experimental studies-descriptive case study technique, statistical analytic and correlation displayed in the average value and standard deviation (SD). The length of female $D$. inustus reproductive organ was $18.88 \pm 0.78 \mathrm{~cm}$ (left) and $19.00 \pm 0.78 \mathrm{~cm}$ (right). The length of ovarian was $1 \mathrm{~cm}$ (left/right), the weights of left and right of ovarian weight were $0.59 \pm 0.85 \mathrm{~g}$ (left) and $1 \mathrm{~g}$ (right), respectively. Diameter and length of fallopian tube, uterine horn, corpus uteri, and cervical were $0.57 \pm 0.01 \mathrm{~mm}$ (left) and $0.60 \pm 0.01 \mathrm{~mm}$ (right) and $3.00 \mathrm{~cm}$ (left) and $3.26 \pm 0.18 \mathrm{~cm}$ (right); $0.54 \pm 0.02 \mathrm{~mm}$ (left) and $0.56 \pm 0.02 \mathrm{~mm}$ (right) and $4 \mathrm{~cm}$ (left) and $4.8 \pm 0.45 \mathrm{~cm}$ (right); $1.16 \pm 0.09 \mathrm{~mm}$ (left) and $1.3 \pm 0.12 \mathrm{~mm}$ (right) and $1 \mathrm{~cm}$ (left/right); $0.3 \mathrm{~mm}$ (left/right) and $3 \mathrm{~cm}$ (left/right), respectively. Length of vagina and vulva were 4 and $2 \mathrm{~cm}$, respectively. The result showed that shape and model of D. inustus reproductive organs were similar with the mammalian female reproductive organs in general but all of the organs have two sparated parts with different sizes.

(Key words: Female reproductive organs, Gray Tree Kangaroo)

\footnotetext{
* Korespondensi (corresponding author):

Telp.+62 85234662992

E-mail: koiburdipapua@yahoo.com
} 


\section{Pendahuluan}

Papua yang merupakan penyumbang keanekaragaman hayati terbesar di Indonesia, secara khusus untuk keberadaan satwa liar dilaporkan oleh WWF Regional Papua (2007) bahwa keberadaan satwa liar di Papua mulai terancam dan mengarah pada kelangkaan dan kepunahan. Hal ini disebabkan karena Papua kaya akan deposit dan minyak bumi sehingga menarik para investor untuk melakukan eksploitasi tambang dan gas secara besar-besaran. Ancaman lainnya adalah rencana pembangunan wilayah seperti pembangunan area industri berskala besar di Mamberamo, perluasan perkebunan kelapa sawit, pembangunan jalan Trans-Papua, konsesi hutan dan pengembangan wilayah pemukiman penduduk sebagai akibat dari pengembangan wilayah pemerintahan di seluruh Papua.

Kanguru Pohon (Dendrolagus sp) adalah salah satu satwa endemik Papua yang merupakan satu dari dua jenis mamalia darat terbesar di Papua yang telah dikenal dan dimanfaatkan oleh masyarakat Papua. Berdasarkan Surat Keputusan Menteri Pertanian Nomor 247/Kpts/Um/4/1979 tanggal 5 April 1979, spesies ini termasuk dalam spesies satwa yang dilindungi oleh pemerintah (Primack et al., 1998), tetapi intensitas perburuan terhadap satwa ini terus berlangsung. Petocz (1987) menyatakan bahwa satwa ini merupakan hewan yang sering diburu oleh masyarakat Papua yang berada dekat dengan hutan-hutan primer dan lindung di Papua untuk dimanfaatkan sebagai sumber protein hewani selain Macropus sp, bandikut, phalangeridae, serta satwa unggas lain. Koibur (2006) melaporkan di Angkaisera Yapen Papua, Kanguru Pohon Kelabu (Dendrolagus inustus) diburu oleh masyarakat menggunakan senjata tradisional (parang, tombak, busur-panah), senjata modern dan jerat untuk dikonsumsi dan dijual dalam bentuk hidup atau mati dengan harga Rp. 500.000,00 - 1.000.000,00/ekor. Yepasedanya (2003) dan Gombo (2004) melaporkan D. inustus dapat hidup dengan baik di penangkaran serta cepat beradaptasi dengan lingkungannya yang baru.

Pengetahuan tentang reproduksi Kanguru Pohon umumnya dan Kanguru Pohon Kelabu khususnya di Papua masih sangat terbatas atau bahkan belum sama sekali diungkapkan dalam berbagai penelitian. Penelitian-penelitian selama ini hampir semuanya pada kanguru yang terdapat di Australia. Aspek reproduksi sangat vital dalam pengembangan suatu satwa atau ternak, tanpa pengetahuan tentang reproduksi maka upaya-upaya budidaya dan pengembangan suatu satwa atau ternak akan sia-sia belaka. Penelitian tentang tingkah laku harian Kanguru Pohon Kelabu di dalam penangkaran yang menyangkut tingkah laku makan, minum, bermain, beristirahat dan reproduksi telah dilakukan Yepasedanya (2003). Secara khusus untuk tingkah laku reproduksi pada penelitian ini hanya merupakan data sekunder jadi intensitas pengamatan dan spesifik tingkah laku reproduksinya kurang tergambarkan.

Sifat-sifat reproduksi Kanguru Pohon Kelabu betina menyangkut dewasa kelamin, tingkah laku kawin terutama karakteristik organ reproduksi betina (struktur dan morfologi) adalah informasi dasar (database) yang mestinya diketahui dalam upaya pengembangan satwa ini ke depan.

Demi menjawab permasalahan di atas dibutuhkan suatu penelitian yang dapat memberikan gambaran kondisi nyata ukuran dan bentuk organ reproduksi Kanguru Pohon Kelabu betina, sehingga penelitian ini dianggap penting untuk dilakukan.

Penelitian ini bertujuan mempelajari karakteristik organ reproduksi Dendrolagus inustus betina. Hasil penelitian ini diharapkan dapat menjadi pengetahuan baru di dunia biologi khususnya reproduksi tentang karakteristik organ reproduksi betina Dendrolagus inustus serta sebagai informasi dan acuan bagi mahasiswa, masyarakat, pemerhati satwa, pemerintah daerah dan semua pihak yang berkeinginan untuk melaksanakan budidaya $D$. inustus.

\section{Materi dan Metode}

Kegiatan penelitian ini dilaksanakan di Sub Laboratorium Reproduksi Ternak, Kesehatan Hewan, dan Satwa Liar pada Laboratorium Produksi Ternak, Jurusan Produksi Ternak, Fakultas Peternakan Perikanan dan Ilmu Kelautan, Universitas Negeri Papua, Manokwari, Papua Barat. Penelitian dilakukan mulai September 2009 sampai dengan September 2010.

\section{Materi}

Penelitian ini menggunakan lima (5) buah organ reproduksi betina Kanguru Pohon Kelabu ( $D$. inustus) dewasa. Peralatan yang digunakan antara lain: seperangkat alat bedah, timbangan kapasitas $200 \mathrm{~g}$ (Ohause Jepang), penggaris/pita ukur, timbangan gantung digital kapasitas $25 \mathrm{~kg}$, parang, kayu, calliper, kamera, dan alat tulis menulis.

\section{Metode}

Metode studi eksperimen-deskriptif dengan teknik studi kasus. Karakteristik organ reproduksi betina $D$. inustus adalah kasus yang diteliti. Pelaksanaan penelitian dilakukan dalam 2 tahap, yaitu persiapan penelitian dan pelaksanaan penelitian.

Persiapan penelitian mencakup, pengadaan D. inustus, dan penyediaan sarana prasarana 
penelitian. D. inustus yang dipakai pada penelitian ini dibeli dari masyarakat di Kab. Kepulauan Yapen seharga Rp. 1.500.000,00/ekor dan Kab. Manokwari Rp. 1.000.000,00/ekor. D. inustus dari Kab. Kepulauan Yapen lalu dimuat dengan kapal laut ke Kab. Manokwari sebagai lokasi pelaksanaan penelitian, menempuh jarak 1.500 mil selama 14 jam perjalanan. Proses pembelian dan pengangkutan terjadi dalam 2 periode yaitu pada pertengahan September 2009 sebanyak 2 ekor dan awal Desember 2009 sebanyak 1 ekor. Sedangkan $D$. inustus yang berasal dari Kab. Manokwari dibeli pada Maret 2010 sebanyak 1 ekor dan Juli 2010 sebanyak 2 ekor.

Dalam pelaksanaan penelitian dilakukan beberapa kegiatan yaitu identifikasi/penafsiran umur dan pembedahan. Sebelum D. inustus yang diperoleh dibedah untuk diambil organ reproduksinya terlebih dahulu diidentifikasi/ditafsir umurnya, hal ini dimaksud untuk menyeragamkan umur $D$. inustus, sehingga data ukuran organ reproduksi yang diperoleh juga berada pada kisaran tingkat kedewasaan D. inustus yang sama. Tafsiran umur/kedewasaan $D$. inustus merujuk pada berat badan saat ditimbang, panjang tubuh saat diukur dan informasi lama dipelihara oleh pemiliknya sebelum dibeli untuk menaksir lama hidup yang tentunya dapat menjadi gambaran umur $D$. inustus saat ini. Lima ekor D. inustus yang dipakai organ reproduksinya adalah yang ditafsir memiliki umur 1 s/d 2,5 tahun.

Proses pembedahan didahului dengan membunuh $D$. inustus. Proses pembunuhan $D$. inustus dilakukan mengikuti pola masyarakat saat membunuh $D$. inustus untuk dikonsumsi, yaitu memukul bagian belakang kepala $D$. inustus hingga mati menggunakan alat tumpul, kemudian dibedah memakai peralatan bedah yang telah disiapkan untuk diambil organ reproduksi betinanya, lalu dibersihkan organ reproduksi tadi dari lemak, kulit dan darahnya, dan mengamati organ reproduksi betina $D$. inustus.

\section{Variabel pengamatan}

Variabel yang diamati dalam penelitian ini meliputi variabel utama dan variabel penunjang. Varibel utama adalah karakteristik organ reproduksi betina yang terdiri atas bentuk/morfologi dan panjang organ reproduksi betina, panjang dan berat Ovarium, panjang dan diameter tuba fallopii, panjang dan diameter cornu dan corpus uteri, panjang dan diameter luar serviks, serta ukuran vagina dan vulva.
Pengukuran panjang keseluruhan organ reproduksi $D$. inustus dari ujung bagian atas ovarium hingga ujung bawah klitoris menggunakan mistar/pita ukur dengan memakai rerata hasil pengukuran antara panjang dari ovarium hingga klitoris kanan dan panjang ovarium hingga klitoris kiri sebagai panjang keseluruhan tiap sisi organ reproduksi betina $D$. inustus dalam satuan $\mathrm{cm}$.

Panjang ovarium $D$. inustus diukur menggunakan pita ukur dalam satuan $\mathrm{cm}$. Cara pengukurannya adalah pita ukur pada angka 0 (nol) diletakkan pada ujung bawah ovarium lalu ditarik hingga ujung atas ovarium, dan dibaca panjang ovarium. Rerata panjang ovarium kanan dan kiri dinyatakan sebagai kisaran panjang ovarium $D$. inustus.

Berat ovarium diukur menggunakan timbangan analitik merek Ohause berkapasitas $200 \mathrm{~g}$. Cara pengukurannya adalah mengaktifkan timbangan analitik Ohause dan menormalkan skalanya hingga mencapai angka 0 (nol), lalu ovarium diletakkan pada timbangannya maka akan terbaca berat ovarium yang ditampilkan pada skala timbangan analitik Ohause dalam satuan gram $(\mathrm{g})$. Rerata berat ovarium kanan dan kiri dinyatakan sebagai kisaran berat ovarium $D$. inustus .

Panjang tuba fallopii diukur menggunakan mistar/pita ukur dalam satuan $\mathrm{cm}$. Cara pengukurannya dengan meletakkan mistar/pita ukur pada skala 0 (nol) di ujung bawah tuba fallopii yang bertautan dengan cornu uteri dan membaca angka terakhir pada mistar/pita ukur yang tampak pada ujung bagian atas tuba fallopii yang bertautan dengan ovarium. Rerata panjang tuba fallopii kanan dan kiri dinyatakan sebagai kisaran panjang tuba fallopii D. inustus.

Diameter tuba fallopii diukur menggunakan calliper dalam satuan mm. Cara pengukurannya dengan meletakkan tuba fallopii pada tangkai skala calliper lalu merapatkannya hingga tuba fallopii tertekan pada kedua sisi, dengan demikian dapat terbaca diameter tuba fallopii. Rerata diameter tuba fallopii kanan dan kiri dinyatakan sebagai kisaran diameter tuba fallopii D. inustus.

Panjang cornu uteri diukur menggunakan mistar/pita ukur dalam satuan $\mathrm{cm}$. Cara pengukurannya dengan meletakkan mistar/pita ukur pada skala 0 (nol) di ujung bawah cornu uteri yang bertautan dengan corpus uteri dan membaca angka terakhir pada mistar/pita ukur yang tampak pada ujung bagian atas cornu uteri yang bertautan dengan tuba fallopii. Rerata panjang cornu uteri kanan dan kiri dinyatakan sebagai kisaran panjang cornu uteri D. inustus. 
Diameter cornu uteri diukur menggunakan calliper dalam satuan $\mathrm{mm}$. Cara pengukurannya dengan meletakkan cornu uteri pada tangkai skala calliper lalu merapatkannya hingga cornu uteri tertekan pada kedua sisi, dengan demikian dapat terbaca diameter cornu uteri. Rerata diameter cornu uteri kanan dan kiri dinyatakan sebagai kisaran diameter cornu uteri D. inustus.

Panjang corpus uteri diukur menggunakan mistar/pita ukur dalam satuan $\mathrm{cm}$. Cara pengukurannya dengan meletakkan mistar/pita ukur pada skala 0 (nol) di ujung bawah corpus uteri yang bertautan dengan serviks dan membaca angka terakhir pada mistar/pita ukur yang tampak pada ujung bagian atas corpus uteri yang bertautan dengan cornu uteri. Rerata panjang corpus uteri kanan dan kiri dinyatakan sebagai kisaran panjang corpus uteri D. inustus.

Diameter corpus uteri diukur menggunakan calliper dalam satuan $\mathrm{mm}$. Cara pengukurannya meletakkan corpus uteri pada tangkai skala calliper lalu merapatkannya hingga corpus uteri tertekan pada kedua sisi, dengan demikian dapat terbaca diameter corpus uteri. Rerata diameter corpus uteri kanan dan kiri dinyatakan sebagai kisaran diameter corpus uteri D. inustus.

Panjang serviks diukur menggunakan mistar/pita ukur dalam satuan $\mathrm{cm}$. Cara pengukurannya dengan meletakkan mistar/pita ukur pada angka 0 (nol) di ujung bawah serviks yang bertautan dengan vagina dan membaca angka terakhir pada mistar/pita ukur yang tampak pada ujung bagian atas serviks yang bertautan dengan corpus uteri. Rerata panjang serviks kanan dan kiri dinyatakan sebagai kisaran panjang serviks $D$. inustus.

Diameter serviks diukur menggunakan calliper dalam satuan $\mathrm{mm}$. Cara pengukurannya dengan meletakkan serviks pada tangkai skala calliper lalu merapatkannya hingga serviks tertekan pada kedua sisi, dengan demikian dapat terbaca diameter serviks. Rerata diameter serviks kanan dan kiri dinyatakan sebagai kisaran diameter serviks $D$. inustus.

Vagina diukur menggunakan mistar/pita ukur dalam satuan $\mathrm{cm}$. Cara pengukurannya dengan meletakkan mistar/pita ukur pada angka 0 (nol) di ujung bawah vagina yang bertautan dengan vulva dan membaca angka terakhir pada mistar/pita ukur yang tampak pada ujung bagian atas vagina yang bertautan dengan serviks. Rerata panjang vagina kanan dan kiri dinyatakan sebagai kisaran panjang vagina $D$. inustus.

Vulva diukur menggunakan mistar/pita ukur dalam satuan $\mathrm{cm}$. Cara pengukurannya dengan meletakkan mistar/pita ukur pada angka 0 (nol) di klitoris yang bertautan dengan vulva dan membaca angka terakhir pada mistar/pita ukur yang tampak pada ujung bagian atas vulva yang bertautan dengan vagina. Rerata panjang vulva kanan dan kiri dinyatakan sebagai kisaran panjang vulva $D$. inustus.

Variabel penunjang yang meliputi bobot badan, umur dan panjang tubuh Kanguru Pohon Kelabu. Bobot badan diukur menggunakan timbangan digital gantung kapasitas $25 \mathrm{~kg}$. Umur diduga berdasarkan fase hidup saat ditangkap masyarakat, lama dipelihara sebelum dibeli, bobot badan dan panjang tubuh saat penelitian. Panjang tubuh diukur menggunakan pita ukur $(\mathrm{cm})$ dimulai dari moncong hingga pangkal ekor Kanguru Pohon Kelabu.

\section{Analisis data}

Data yang dikumpulkan diolah dan dianalisis secara statistik deskriptif dan korelasi untuk beberapa bagian yang diperlukan dan ditampilkan dalam rerata dan standar deviasi (SD).

\section{Hasil dan Pembahasan}

\section{Pendugaan fase hidup kanguru pohon kelabu ( $D$. inustus) betina}

Hasil dari penelitian ini menunjukkan bahwa D. inustus yang digunakan rerata berumur $1,8 \pm 0,45$ tahun. Umur $D$. inustus diduga berdasarkan bobot badan, fase perkembangan saat ditangkap dan lamanya dipelihara oleh masyarakat sebelum dibeli, dan panjang tubuh $D$. inustus saat penelitian.

Petocz (1994), melalui penelusurannya pada kehidupan Kanguru Pohon di Papua, menyatakan bahwa anak Kanguru Pohon masih mungkin berada dalam kantung induknya hingga berumur 6 bulan karena selama itu proses pertumbuhan dan perkembangan yang kedua terjadi hingga tumbuhnya bulu pada seluruh tubuh kanguru, setelah itu anak tersebut akan hidup mandiri dengan mencari makanan sendiri namun tidak menutup kemungkinan untuk kembali menyusui pada puting induknya tanpa melukai saudaranya yang lebih muda jika ada kelahiran berikutnya.

Pendapat ini didukung Newsome (2002), atas risetnya pada Kanguru Merah di Australia Tengah yang mendapatkan anak kanguru selama kurang lebih 200 hari masih berada dalam kantung induknya dan baru secara penuh meninggalkan kantung induknya pada umur 240 hari. Bayi kanguru lahir buta, tak berbulu dan tinggal di kantung induknya dengan mendapatkan makanan melalui susu induknya, dan anak kanguru tersebut masih berada di kantung induknya selama kurang lebih 9 bulan (Anonimus, 2005).

Kematangan seks betina D. inustus dapat diduga melalui bobot badannya. Kanguru Pohon Kelabu betina dalam penelitian ini memiliki bobot badan rerata $10,83 \pm 1,03 \mathrm{~kg}$. Flannery (1995) 
melaporkan, Kanguru Pohon betina pada bobot badan 8-10 kg telah mencapai dewasa kelamin. Panjang tubuh Kanguru Pohon juga dapat menjadi indikator kedewasaan. Hasil penelitian diperoleh rerata panjang tubuh $D$. inustus $72,8 \pm 3,96 \mathrm{~cm}$. Flassy (2007) menyatakan seekor Kanguru Pohon dengan panjang tubuh antara 500-800 $\mathrm{mm}$ telah memasuki fase dewasa tubuh.

\section{Karakteristik organ reproduksi betina kanguru pohon kelabu}

Organ reproduksi Kanguru Pohon Kelabu betina yang diperoleh dalam penelitian ini, memiliki susunan dan bentuk yang menyerupai organ-organ reproduksi betina mamalia pada umumnya, dan sepintas memiliki kemiripan dengan organ reproduksi betina anjing (Yatim, 1990). Akan tetapi masing-masing organ tersebut berpasang-pasangan dan dipisahkan oleh sekat yang jelas. Organ-organ itu antara lain ovarium atau gonad sebagai alat kelamin utama, saluran-saluran reproduksi yang terdiri dari tuba fallopii, cornu dan corpus uteri, serviks, vagina, dan organ kelamin luar yang terdiri dari vulva dan klitoris.

Panjang organ reproduksi betina Kanguru Pohon Kelabu yang diperoleh dalam penelitian ini berkisar antara 18,88 $\pm 0,78 \mathrm{~cm}$ (kiri) dan 19,00 $\pm 0,77$ $\mathrm{cm}$ (kanan). Panjang organ reproduksi memiliki korelasi positif dengan panjang tubuh dan berat badan, namun tidak memiliki hubungan dengan umur Kanguru Pohon Kelabu. Hafez (2000) menyatakan bahwa panjang organ reproduksi individu ternak memiliki hubungan positif dengan panjang tubuh, bobot badan dan umur hidup individu ternak itu sendiri. Tidak adanya hubungan umur Kanguru Pohon Kelabu dengan bobot badan, panjang tubuh dan panjang organ reproduksinya diduga akibat minimnya materi yang dipakai dalam penelitian ini.

Ovarium $D$. inustus dari hasil penelitian diketahui berbentuk oval, dengan kisaran panjang 1 $\mathrm{cm}$ (kiri/kanan), dan kisaran berat antara 0,59 $\pm 0,09$ g (kiri) dan $0,65 \pm 0,17 \mathrm{~g}$ (kanan). Berat ovarium $D$. inustus sangat ringan jika dibandingkan dengan berat ovarium pada sapi (10-20 g), domba (3-4 g) dan kerbau (3,97 g) (Murti, 2002). Secara individu Kanguru Pohon Kelabu 2 memiliki berat yang lebih besar $(0,93 \mathrm{~g})$ pada ovarium kanan dan Kanguru Pohon Kelabu 1 memiliki berat paling kecil $(0,50 \mathrm{~g})$ pada ovarium kiri, kondisi ini diduga akibat dari adanya perkembangan folikel di dalam ovarium yang telah memasuki fase de Graaf dan perkembangan ovarium kiri khususnya maupun organ kelamin betina $D$. inustus bagian kiri sedikit terhambat.
Toelihere (1985) melaporkan bahwa besar ovarium yang tentunya berpengaruh pada berat ovarium erat hubungannya dengan jumlah folikel de Graaf yang terbentuk, lebih jauh dijelaskan jumlah folikel de Graaf yang terbentuk tergantung pada hereditas dan faktor-faktor lingkungan. Hardjopranjoto (1995) menegaskan adanya kejadian pada satu individu ternak, dapat terjadi pada salah satu organ atau keseluruhan salah satu bagian organ kelaminnya (jantan maupun betina) kemungkinan mengalami abnormalitas perkembangan yang bersifat genetik maupun lingkungan sehingga organ tersebut cenderung lebih besar atau kecil dari kondisi normal umumnya. Pendapat ini dibenarkan Hafez (2000) yang menyatakan bahwa ada kecenderungan salah satu atau seluruh bagian organ reproduksi (jantan maupun betina) bagian kiri (terkadang kanan namun jarang ditemukan) mengalami perkembangan yang tidak sempurna (rudimenter) sehingga tampak sangat kecil bahkan tidak ada, yang diduga sebagai akibat pengaruh lingkungan maupun hereditas individu ternak dimaksud.

Tuba fallopii/oviduct $D$. inustus berbentuk bulat kecil dan panjang, ujungnya menyerupai corong. Diameternya berkisar $0,57 \pm 0,01 \mathrm{~mm}$ (kiri) dan $0,60 \pm 0,05 \mathrm{~mm}$ (kanan), panjang berkisar $3,00 \pm 0,00 \mathrm{~cm}$ (kiri) dan 3,26 $\pm 0,18 \mathrm{~cm}$ (kanan). Panjang tuba fallopii Kanguru Pohon Kelabu lebih pendek dari panjang tuba fallopii beberapa mamalia lain (sapi $25 \mathrm{~cm}$; domba 15-29 $\mathrm{cm}$; kerbau (22-28 cm) (Murti, 2002); babi 15-30 cm dan kuda 20-30 cm) (Hafez, 2000).

Cornu uteri D. inustus yang diperoleh pada penelitian ini berbentuk tanduk bulat panjang sedikit lebih besar jika dibandingkan dengan tuba fallopii, memiliki kisaran diameter antara 0,54 \pm $0,02 \mathrm{~mm}$ (kiri) dan $0,56 \pm 0,02 \mathrm{~mm}$ (kanan) dan

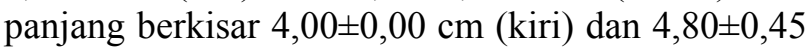
cm (kanan). Cornu uteri D. inustus lebih pendek jika dibandingkan sapi $(35-40 \mathrm{~cm})$; domba $(10-12$ $\mathrm{cm})$ dan kerbau (21,2 cm) (Murti, 2002).

Kanguru Pohon Kelabu 2 memiliki diameter uterus yang lebih besar $(0,60 \mathrm{~mm})$. Keadaan ini diduga merupakan pertanda belum sempurnanya proses involusi pada uterus karena Kanguru Pohon Kelabu 2 memiliki anak, yang umurnya kira-kira 12 minggu. Sharman (1970) berpendapat bahwa lama bunting seekor kanguru adalah 33 hari. Ada sebagian kanguru yang dapat langsung kembali birahi lagi tanpa melalui proses involusi tetapi juga ada sebagian yang membutuhkan waktu 1-2 minggu untuk proses involusi guna persiapan kebuntingan dan kelahiran berikutnya. 
Corpus uteri D. inustus berbentuk bulat dan ketika disentuh/dipegang terasa tebal, hasil penelitian memperlihatkan diameter dan panjang corpus uteri D. inustus berkisar $1,16 \pm 0,09 \mathrm{~mm}$ (kiri) dan 1,30 $\pm 0,12 \mathrm{~mm}$ (kanan); 1,00 cm (kiri/kanan). Panjang corpus uteri pada $D$. inustus dibandingkan dengan beberapa mamalia yang telah didomestikasi terdapat kedekatan ukuran maupun perbedaan yang cukup mencolok seperti: sapi 2-4 cm; domba 1-2 $\mathrm{cm}$; kerbau 1,75 cm (Murti, 2002); babi $5 \mathrm{~cm}$ dan kuda 15-20 cm (Hafez, 2000).

Serviks D.inustus berbentuk bulat panjang, dipegang bagaikan daging berbentuk cincin yang bertumpuk dan sangat kenyal. Memiliki kisaran panjang $3 \mathrm{~cm}$ (kiri/kanan) dan diameter $0,3 \mathrm{~mm}$ (kiri/kanan). Bentuk serviks Kanguru Pohon Kelabu menyerupai bentuk serviks mamalia umumnya, sebagaimana pendapat Toelihere (1985) bahwa bentuk serviks sapi, domba, babi dan kuda memiliki lumen yang berbentuk cincin annuler, sekrup pembuka botol dan memiliki lipatan-lipatan yang jelas dan sangat alot atau kenyal ketika dipegang. Kondisi ini disinyalir Hafez (2000) sebagai akibat dari sifat serviks yang selektif permiabel terhadap segala zat yang hendak masuk ke dalam uterus.

Panjang serviks $D$. inustus ini lebih pendek dari sapi $(8-10 \mathrm{~cm})$, domba $(4-10 \mathrm{~cm})$, kerbau $(5,2-$ $5,9 \mathrm{~cm}$ ) (Murti, 2002), babi $(10 \mathrm{~cm})$ dan kuda $(7-8$ $\mathrm{cm})$ (Hafez, 2000). Perbedaan ini menurut Hafez (2000), Toelihere (1985), Partodihardjo (1982) dan Yatim (1990) disesuaikan dengan bentuk dan panjang penis jantan tiap hewan ini. Sharman (1970) dan King (2001), menyatakan serviks kanguru terdapat dua pasang yang disesuaikan dengan bentuk penis jantannya yang menyerupai garpu.

Vagina D. inustus memiliki bentuk bulat panjang dengan kontur yang lembut dan hymennya tampak jelas, panjangnya mencapai $4 \mathrm{~cm}$ (kiri/kanan). Dibandingkan dengan mamalia lain kanguru memiliki ukuran panjang vagina yang kecil, sapi $(25-30 \mathrm{~cm})$ dengan hymen yang tidak jelas; domba 10-14 cm hymen berkembang baik; babi 10-15 cm hymen tidak jelas dan kuda $20-35 \mathrm{~cm}$ dengan hymen yang berkembang baik (Hafez, 2000). Pendeknya ukuran vagina $D$. inustus diduga berhubungan erat dengan panjang dan bentuk penis pejantannya, sebagaimana pendapat Sharman (1970) dan King (2001).

Organ kelamin luar $D$. inustus berupa vulva dan klitoris, pada penelitian ini diketahui bahwa ternyata vulva dan klitoris Kanguru Pohon Kelabu juga terdapat 2 buah dan keduanya (kanan dan kiri) berkembang dengan baik. Sharman (1970) dan King (2001) menduga berkembang sempurnanya kedua vulva dan klitoris (kanan dan kiri) berkaitan dengan bentuk penis pejantan yang menyerupai garpu.
Vulva berbentuk kumpulan daging yang memiliki penampakan hymen yang sangat jelas dengan kontur yang sangat lembut, sementara klitoris tampak seperti timbunan daging yang menyerupai kacang yang timbul keluar dari vulva. Rerata panjang vulva dalam penelitian ini mencapai $2 \mathrm{~cm}$ (kiri/kanan).

\section{Kesimpulan}

Organ kelamin betina Kanguru Pohon Kelabu (Dendrolagus inustus) memiliki bentuk, model dan sebutan yang menyerupai organ kelamin betina mamalia umumnya akan tetapi keseluruhannya berpasangan dengan sekat pemisah yang jelas dan berbeda ukuran. Organ kelamin betina Kanguru Pohon Kelabu (Dendrolagus inustus) bagian kanan mengalami perkembangan yang lebih sempurna dari bagian kiri. Perlu dilakukan penelitian lanjutan untuk mempelajari tingkah laku reproduksi dan fisiologi reproduksi Kanguru Pohon Kelabu dalam penangkaran.

\section{Daftar Pustaka}

Anonimus. 2005. Reproduction Kangaroo. Available at http://encarta.msn.com. Accession date: April 10, 2009.

Flannery, T. 1995. Mamals of New Guinea. Australian Museum.

Flassy, D.A. 2007. Fauna Tanah Kita untuk Pengenalan di Sekolah dan Pengetahuan Umum. Balai Pustaka. Jakarta.

Gombo, H. 2004. Tingkat kesukaan Kanguru Pohon Kelabu terhadap beberapa jenis pakan dalam penangkaran di kampung Famboaman Distrik Yapen Selatan Kabupaten Yapen Waropen. Skripsi Sarjana Peternakan FPPK UNIPA. Manokwari.

Hafez, E.S.E. 2000. Anatomy of Female Reproduction, in Reproduction in Farm Animals, Hafez, E.S.E. ad, $7^{\text {th }}$ ed. Lea \& Febiger. Philadelphia.

Hardjopranjoto, S.H. 1995. Ilmu Kemajiran Pada Ternak. Airlangga University Press. Surabaya.

King, A. 2001. Discoveries about Marsupial Reproduction. Available at www.biology. iastate.edu. Accession date: April 12, 2009.

Koibur, J.F. 2006. Perburuan Kanguru Pohon Kelabu (Dendrolagus inustus) dan pemanfaatannya oleh masyarakat Angkaisera di Yapen Papua. Laporan Penelitian Dosen Muda Dirjen Dikti Jakarta.

Murti, T.W. 2002. Ilmu Ternak Kerbau. Percetakan Kanisius, Yogyakarta.

Newsone, A.E. 2002. Reproduction in natural populations of the red kangaroo, Megaleia 
rufa (Desmarest), in central Australia. Aust. J. Zool. 13(5): 735-760.

Partodihardjo, S. 1982. Ilmu Reproduksi Hewan. Penerbit Mutiara. Jakarta.

Petocz, R.G. 1987. Konservasi Alam dan Pembangunan Irian Jaya. Graffiti Press, Jakarta. 1994. Mamalia Darat Irian Jaya. Gramedia. Jakarta.

Primack, R.B., J. Supriatna, M. Indrawan, dan P. Kramadibrata. 1998. Biologi Konservasi. Yayasan Obor Indonesia, Jakarta.

Sharman, G.B. 1970. Reproductive Physiology of Marsupials. Science 167 (3922): 1221-1228.
Toelihere, M.R. 1985. Fisiologi Reproduksi Pada Ternak. Penerbit Angkasa Bandung. Bandung.

WWF Regional Papua. 2007. Laporan Tahunan. Jayapura.

Yatim, W. 1990. Reproduksi dan Embriologi. Penerbit PT. Tarsito. Bandung.

Yepasedanya, S. 2003. Tingkah laku harian Kanguru Pohon Kelabu (Dendrolagus inustus) dalam penangkaran di Kampung Famboaman Distrik Yapen Selatan Kabupaten Yapen Waropen. Skripsi Sarjana Peternakan FPPK UNIPA. Manokwari. 